\title{
APPLICATION OF THE COMPETENCY-BASED APPROACH IN ORGANISATIONS IN THE CZECH REPUBLIC
}

\author{
Martina Fejfarová, Hana Urbancová
}

\section{Introduction}

A competency-based approach is one of the important tools of human resource management aimed at achieving strategic organisational goals [3], [25], [13], [6], [24], [27], [12]. In compliance with a resource-based approach to achieve a competitive advantage, it is necessary for organisations to identify, evaluate and develop key employee's competencies in order to achieve a competitive advantage [6], [20], [22]. The application of competencies in the management process enables organisation's requirements and employee's opportunities to interlink in a way to permit their development in mutual harmony and ensure organisation's competitiveness in a market. The emphasis on knowledge, service, and information in the new economy creates space for more new organisations to emerge, and exerts pressures on existing organisations to hire employees with higher level skills in order to compete successfully [4].

According to Mitchelmore and Rowley [18], competency is a concept that has many faces and applications. Research and practice related to competencies are typically driven by aspirations to achieve a superior performance (on an individual or organisational level). The competency-based approach to human resource management is not a new approach [22]. According to its development, it is possible to divide competencies into three main development phases.

The first phase consists of individual competencies, i.e. individual characteristics necessary to reach the required level of an employee's performance. The beginnings of this phase date back to 1959 when White [28] used, for the first time, the term "competence". Later psychologists and management theoreticians started to address the issue whether (and to what extent) competencies may determine a suitable candidate for a job position. There are two conceptions of competencies which are based on differences between terms "competence" and "competency". In this article we use the term "competency" defined by Boyatzis [3].

Managerial competencies are a specific type of individual competencies; e.g. specific knowledge, abilities, skills, traits, motives, attitudes and values necessary to improve management performance. These performancebased competencies are assessed through observed behaviours [7]. Additionally, the literature also identifies other components of managerial competencies which also contribute significantly to career success [3], [25], [26], [30], [13], [29], [2], [24], [12].

The second phase is based on the possibility of managing competencies in an organisation by means of competency models. Competency models originated in the USA and exploit a number of methods that are commonly used in traditional analyses of work positions. They were developed as a response to dissatisfaction with candidate testing that was to determine a suitable employee for the given position [17]. According to Mansfield [14], in recent years, organisations have begun to use competency models in new ways. These new competency models, of necessity, describe emerging and anticipated skill requirements, rather than skills that have been effective in the past. Because organisations are changing more rapidly, the "shelf life" of the competency model has diminished. Frequent reorganisations change job roles and make existing job descriptions and competency models obsolete.

Competencies and competency models are today commonly practiced in most of organisations [27]. There are a number of approaches to a competency-based model development [22]. It is therefore necessary for 
management to select, based on an analysis, such the approach to competency-based model development which respects specific environmental conditions and meets the requirements of the given organisation. This is confirmed by Marrelli, Tondora and Hoge [15] who also point out that the application of the competency-based approach must be carefully planned and supported by a leadership of an organisation, and concerted efforts must be made to communicate with those involved or potentially affected. The development and application of managerial competency models in the proven approach for investing in human resources in order to achieve a more effective and productive workforce.

In the 1990s, core competencies of an organisation that form the third phase were identified. The concept of core competencies underlines competency-based competition and competency-based management [21]. Core competencies are a sum of organisation key organisational competencies that may be exploited to gain a competitive advantage. According to Cardy and Selvarajan [6], from a strategic management perspective, Hitt, Ireland, and Hoskisson [11] define competencies as a combination of resources and capabilities. The combination of resources and capabilities in an organisation can be classified as core competencies when they are valuable, rare, difficult to imitate, and difficult to substitute. As such, core competencies can be a source of strategic competitiveness.

The aim of the article is to evaluate, based on an analysis, the competency-based approach in organisations in the Czech Republic and also to identify areas and activities in which the competency-based approach is applied (concentrating on individual categories of employees) and test dependencies between selected qualitative characteristics that relate to the issues examined.

The article is organized as follows. The first part of the article concentrates on a theoretical background of the topic. The second part of the article is dedicated to an evaluation of outcomes of a survey conducted. The article has been produced on a basis of an analysis of primary and secondary sources, in particular research studies focusing on the competencybased approach. Primary data is derived from a questionnaire survey conducted that was focused on an application of the competency- based approach in organisations in the Czech Republic.

\section{Material and Methods}

In the period from 10/2011 to 06/2012 a quantitative survey was conducted, by means of a questionnaire survey, focusing on an evaluation of the level of human resource management in organisations in the Czech Republic. Subsequent to the outcomes of the previous survey (a quantitative content analysis, semi-structured interviews), one part of the survey was targeted at the use of competencies in human resource management. 109 organisations from both the private and public sectors took part in the questionnaire survey. $48.6 \%$ of the organisations surveyed have less than 50 employees, $29.4 \%$ of these organisations have 50 to 249 employees and $22 \%$ of these organisations employ more than 250 people. To enhance the quality of the questionnaire survey and to determine the real level of human resource management in organisations, it was required for the questionnaire to be completed by a specialist from the personnel department or an owner of the given organisation. Out of the respondents, $26.6 \%$ occupy the position of a senior manager in the personnel department of the given organisation, $85 \%$ have worked as personnel specialists for 3 or more years and $52.3 \%$ are university graduates. $43.1 \%$ of the responding organisations have a personnel department. The data have been processed by means of absolute and relative frequencies using the Microsoft Excel 2007 program and the IBM SPSS Statistics 20.

The following nine hypotheses were tested:

1. $\mathrm{H}_{0}$ : The utilisation of the competency-based approach in an organisation does not depend on the size of the organisation.

2. $\mathrm{H}_{0}$ : The utilisation of the competency-based approach in an organisation does not depend on the affiliation of the organisation with a larger group of organisations.

3. $\mathrm{H}_{0}$ : The utilisation of the competencybased approach in an organisation does not depend on the sector in which the organisation operates.

4. $\mathrm{H}_{0}$ : The utilisation of the competencybased approach in an organisation does not depend on the existence of a personnel department.

5. $\mathrm{H}_{0}$ : The utilisation of the competencybased approach in an organisation does 
not depend on the existence of a personnel strategy.

6. $\mathrm{H}_{0}$ : The utilisation of the competency-based approach in an organisation does not depend on the execution of work position analysis.

7. $\mathrm{H}_{0}$ : The utilisation of the competency-based approach in an organisation does not depend on the position of the person responsible for human resource management in top management.

8. $\mathrm{H}_{0}$ : The utilisation of the competency-based approach in an organisation does not depend on the application of knowledge management.

9. $\mathrm{H}_{0}$ : The utilisation of the competency-based approach in an organisation does not depend on the utilisation of knowledge bases.

Testing was done by Pearson's ChiSquare Test ( $\mathrm{X}^{2}$ test) in association tables and contingency tables. To interpret the strength of relationship coefficients (the Phi coefficient, Cramer's coefficient and the Contingency coefficient), a scale according to de Vaus [8] was used.

\section{Results}

\subsection{Application of the Competency- Based Approach in Organisations}

The survey conducted has shown that only $35.8 \%$ of the organisations surveyed employ the competency-based approach. In absolute figures, this means 39 organisations of the selected sample. These organisations use the competencybased approach for employee development (100\%), employee appraisal $(69.2 \%)$, employee selection (64.1\%), employee recruitment (61.5\%), work team development (35.9\%), career planning and management (33.3\%) and for work position analysis $(25.6 \%)$. The areas in which the competency-based approach is taken advantage of are shown in Figure 1.

Organisations using the competency-based approach (35.8\%) concentrate in particular on the following activities: a) competency identification b) competency-based model development c) competency level measuring and d) competency development. The proportional use of these

\section{Fig. 1: Areas of application of the competency-based approach in organisations}

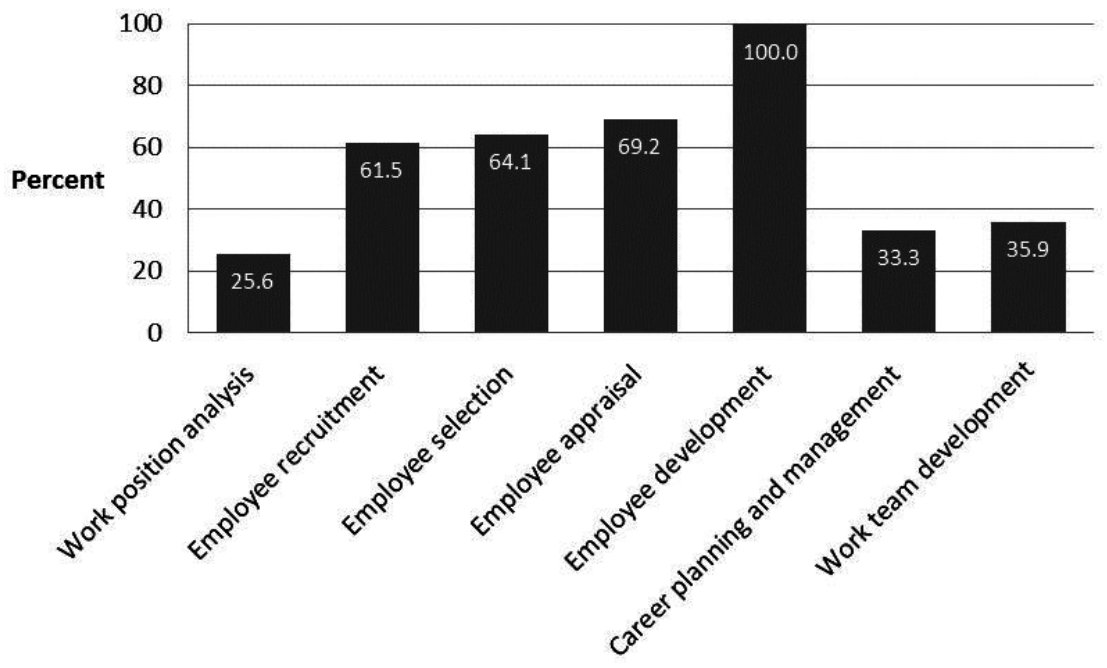

Areas of application of the competency-based approach 


\section{Fig. 2: The proportional use of activities with respect to individual categories of employees}

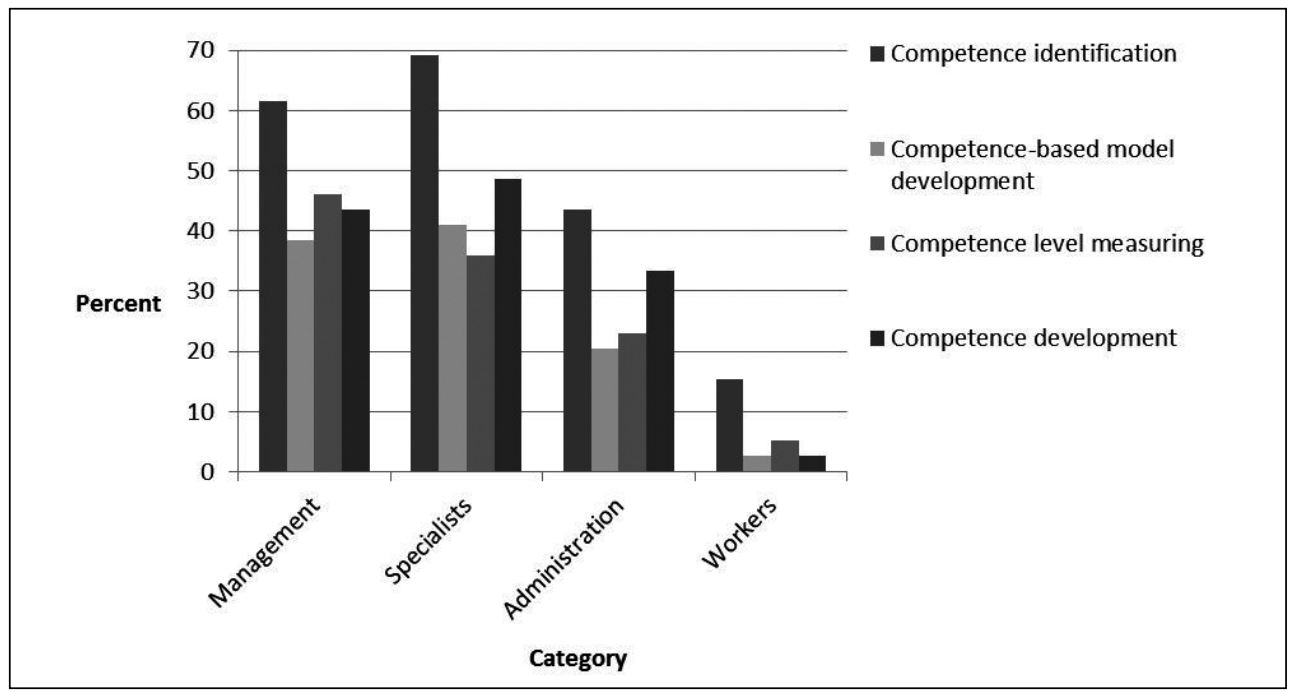

Source: own

activities with respect to individual categories of employees is demonstrated in Figure 2.

It is clear from Figure 2 that individual activities are not used by organisations in a balanced way. This is also valid for individual categories of employees. In the Management category, $74 \%$ of organisations carry out the identification of managerial competencies, $38.5 \%$ of organisations develop managerial competency models, $42.6 \%$ of organisations measure the level of managerial competencies and $43.6 \%$ of organisations engage in managerial competency development. In the Specialists category, $69.2 \%$ of organisations carry out competency identification, $41 \%$ of organisations develop competency-based models, $35.9 \%$ of organisations measure competency levels and $48.7 \%$ of organisations engage in competency development. In the Administration category (Technical and Administrative Staff), $43.6 \%$ of organisations carry out competency identification, $20.5 \%$ of organisations develop competency-based models, $23.1 \%$ of organisations measure competency levels and $33.3 \%$ of organisations engage in managerial competencies development. In the Workers category, $15.4 \%$ of organisations carry out competency identification, and other activities occur rarely in this category. Only
$2.6 \%$ of organisations develop competencybased models, $5.1 \%$ of organisations measure competency levels and $2.6 \%$ of organisations engage in competency development. It follows from the above said that most of responding organisations that employ the competencybased approach focus primarily on competency identification while other activities lag behind.

Based on the findings from the questionnaire, it is possible to say that organisations concentrate on the application of the competency-based approach in individual areas and activities targeted primarily at managers and specialists, rather than on the application of a competencybased model as a whole, which would trigger the synergic effect that this approach facilitates.

\subsection{Comparison of the Use of the Competency-Based Approach in Small, Mid-Sized and Large Organisations}

The survey has revealed that $41 \%$ of organisations which use the competency-based approach have less than 50 employees, $25.6 \%$ of organisations have 50-249 employees and 33.3\% have over 250 employees, i.e. competencies are primarily taken advantage of in small and large organisations. Using extracted data, dependency was tested 
by applying Pearson's Chi-Square Test. The IBM SPSS Statistics 20 program uses the so-called p-value as an output in dependency testing. $\mathrm{P}$-value in hypothesis testing equals the minimum significance level at which the null hypothesis can be rejected. The calculated $p$-value should be lower than the set significance level of 0.05 ; it is possible to say that the null hypothesis, i.e. the hypothesis on the independence of qualitative characteristics, is rejected at the $5 \%$ level of significance. As the $p$-value calculated by means of the $X^{2}$ test of 0.103 is higher than the selected level of significance $\alpha=0.05$, null hypothesis cannot be rejected; see Table 1 . The result of the test has confirmed that the application of the competency-based approach by organisations was not determined by the size of the organisation (the null hypothesis $\left(\mathrm{H}_{0}\right)$ no. 1).

From the point of view of the affiliation of organisations surveyed, $59 \%$ of organisations applying the competency-based approach belong to a larger group of organisations. This arrangement enables the parent organisation to develop competency-based models that individual organisations further apply at local, regional and national levels. In this case it is, however, necessary to respect the local specifics of the organisation in which the model is to be implemented. In the sample examined, cultural differences do not play any significant role as only $21.1 \%$ of organisations applying the competency-based approach run their business on an international scale, i.e. their competency- based models should respect, among other things, the cultural differences of individual countries. The second hypothesis was tested with respect to these results. Based on the $X^{2}$ test, the null hypothesis has been rejected at the $5 \%$ level of significance ( $p$-value $=0.003$ ) and an alternative hypothesis has been accepted. The result has also been confirmed by Fisher's test for $2 \times 2$ contingency tables ( $p$-value $=0.003$ ). The use of the competency-based approach in an organisation is dependent on its affiliation with a larger group of organisations (the alternative hypothesis $\left(\mathrm{H}_{a}\right)$ no. 2). The strength of the relationship between the variables is, according to the value of Phi coefficient (0.283), Cramer's coefficient (0.283) and Contingency coefficient (0.283), direct (with respect to the positive value) and moderate; see Table 1.

The third hypothesis tested whether the application of the competency-based approach in an organisation is dependent on the sector in which the organisation operates. The competency-based approach is applied by $39.7 \%$ of organisations from the tertiary sector, $34.4 \%$ of organisations from the secondary sector and $11.1 \%$ of organisations from the primary sector. Based on the $\mathrm{X}^{2}$ test, the null hypothesis cannot be rejected ( $p$-value $=0.283$ ). As the survey has showed, the use of the competency-based approach does not depend on the sector in which organisations operate; see Table 1.

\section{Tab. 1: The results of the qualitative characteristics test for hypotheses no. 1, 2 and 3}

\begin{tabular}{c|l|c|c|c|c}
$\begin{array}{c}\text { Number of } \\
\text { hypothesis }\end{array}$ & \multicolumn{1}{|c|}{ Null hypothesis $\left(\mathrm{H}_{0}\right)$} & P-value & $\begin{array}{c}\text { Rejection } \\
\text { of } \mathrm{H}_{0}\end{array}$ & $\begin{array}{c}\text { Value of Phi } \\
\text { coefficient }\end{array}$ & $\begin{array}{c}\text { Strength of the } \\
\text { relationship }\end{array}$ \\
\hline 1 & $\begin{array}{l}\text { The utilisation of the competency-based } \\
\text { approach in an organisation does not depend } \\
\text { on the size of the organisation. }\end{array}$ & 0.103 & No & - & - \\
\hline 2 & $\begin{array}{l}\text { The utilisation of the competency-based } \\
\text { approach in an organisation does not depend } \\
\text { on the affiliation of the organisation with a } \\
\text { larger group of organisations. }\end{array}$ & 0.003 & Yes & 0.283 & Moderate \\
\hline 3 & $\begin{array}{l}\text { The utilisation of the competency-based } \\
\text { approach in an organisation does not depend } \\
\text { on the sector in which the organisation } \\
\text { operates. }\end{array}$ & 0.283 & No & - & \\
\hline
\end{tabular}




\subsection{System of Personnel Management in Organisations Employing the Competency- Based Approach}

The system of personnel management in organisations belongs among important factors that determine the application of the competency-based approach in organisations. A personnel department as a specialised workplace creates, organises and supports the system of personnel management in an organisation. More and more dynamic changes in the outer and inner organisational environment create increased requirements for the quality of personnel management and thus the performance of personnel departments. Despite the fact that the need for the establishment of a personnel department is determined by a number of factors (the current situation in the organisation, the size of the organisation, its organisational structure, its purpose of business, the organisation's strategy, the personnel strategy, etc.), the survey has confirmed that the use of the competency-based approach by organisations is dependent on the existence of a personnel department $\left(\mathrm{H}_{\mathrm{a}}\right.$ no. 4).

The survey has revealed that $68.6 \%$ of organisations that do not employ the competency-based approach do not have a personnel department, while $64.1 \%$ of those that employ the competency-based approach do. Simultaneously it has been validated that the need for the establishment of a personnel department grows with the size of the organisation (according to the number of employees). Only $17 \%$ of organisations surveyed with less than 50 employees have a personnel department. In the category of 50 to 249 employees, $50 \%$ of organisations have a personnel department and in among organisations with more than 250 employees $91.7 \%$ of organisations have a personnel department. Based on the $X^{2}$ test, the null hypothesis has been rejected at the $5 \%$ level of significance ( $p$-value $=0.001)$. The result is also confirmed by Fisher's test ( $p$-value = 0.001 ). The strength of the relationship between the variables is, according to the value of $\mathrm{Phi}$ coefficient (0.316), Cramer's coefficient (0.316) and Contingency coefficient (0.302), direct and moderate; see Table 2.

A personnel strategy is one of an organisation's partial strategies linked to the overall strategy of the organisation. It reflects the organisation's long-term goals regarding human resources and plans aimed at achieving these goals and therefore it should be elaborated in writing. Among the organisations surveyed that use the competency-based model, there are $65.8 \%$ of organisations with a personnel strategy formulated in written form, $26.3 \%$ of organisations have a personnel strategy, but not a written version, and only $7.9 \%$ of organisations have no personnel strategy at all. The survey has revealed that the use of the competency-based approach in organisations is dependent on the existence of a personnel strategy $\left(\mathrm{H}_{\mathrm{a}}\right.$ no. 5). Based on the $\mathrm{X}^{2}$ test, the null hypothesis has been rejected at the $5 \%$ level of significance ( $p$-value $=0.006)$. The strength of the relationship between the variables is, according to the value of Phi coefficient (0.310), Cramer's coefficient (0.310) and Contingency coefficient (0.296), direct and moderate; see Table 2.

The position of personnel departments within organisations is changing. Organisations' owners have started to realise the importance of human resources for competitive advantage achieving. Apart from making personnel management an integral part of the organisational structure, it is essential to determine in detail requirements for work positions and job descriptions of not only employees of the personnel department, but also of the rest of the organisation. Job analysis is a very important activity in the system of personnel management. It is a point of departure for the execution of a number of other personnel activities. It provides information on the position and thus creates a picture of an employee who would be suitable for the job. Since competencies always relate to a certain job, they cannot be identified without prior job analysis.

Job analysis is carried out by $55 \%$ of organisations surveyed and $84.6 \%$ of organisations employing the competencybased approach. With respect to the survey conducted, it is possible to state that the use of the competency-based approach by organisations depends on the execution of work position analysis $\left(H_{a}\right.$ no. 6). Based on the $X^{2}$ test, the null hypothesis has been rejected at the $5 \%$ level of significance ( $p$-value $=0.000)$. The result is also confirmed by Fisher's ( $p$-value $=$ 0.001). The strength of the relationship between 
the variables is, according to the value of $\mathrm{Phi}$ coefficient (0.444), Cramer's coefficient (0.444) and Contingency coefficient (0.406), direct and substantial; see Table 2.

The application of the competencybased approach is also determined by the fact whether or not the person responsible for human resource management holds a position in the organisation's top management. If the head of the personnel department belongs to the organisation's strategic management team, $\mathrm{s} /$ he is more likely to push through the interests in the area of human resource management than in the opposite case. In $66.7 \%$ of organisations applying the competency-based approach the person responsible for human resource management holds a position in the organisation's top management. With respect to the survey conducted it is possible to state that the application of the competency-based approach by organisations depends on whether or not the person responsible for human resource management holds a position in the organisation's top management $\left(\mathrm{H}_{\mathrm{a}}\right.$ no. 7). Based on the $X^{2}$ test, the null hypothesis has been rejected at the $5 \%$ level of significance ( $p$-value $=0.036)$. The result is also confirmed by Fisher's test ( $p$-value $=0.046)$. The strength of the relationship between the variables is, according to the value of Phi coefficient (0.201), Cramer's coefficient (0.201) and Contingency coefficient (0.197), direct and low; see Table 2.

Tab. 2: The results of the qualitative characteristics test for hypotheses no. 4, 5, 6 and 7

\begin{tabular}{c|l|c|c|c|c}
$\begin{array}{c}\text { Number of } \\
\text { hypothesis }\end{array}$ & \multicolumn{1}{c|}{ Null hypothesis $\left.\mathbf{H}_{0}\right)$} & P-value & $\begin{array}{c}\text { Rejection } \\
\text { of } \mathrm{H}_{0}\end{array}$ & $\begin{array}{c}\text { Value of Phi } \\
\text { coefficient }\end{array}$ & $\begin{array}{c}\text { Strength of the } \\
\text { relationship }\end{array}$ \\
\hline 4 & $\begin{array}{l}\text { The utilisation of the competency-based } \\
\text { approach in an organisation does not depend on } \\
\text { the existence of a personnel department. }\end{array}$ & 0.001 & Yes & 0.316 & Moderate \\
\hline 5 & $\begin{array}{l}\text { The utilisation of the competency-based } \\
\text { approach in an organisation does not depend on } \\
\text { the existence of a personnel strategy. }\end{array}$ & 0.006 & Yes & 0.310 & Moderate \\
\hline 6 & $\begin{array}{l}\text { The utilisation of the competency-based } \\
\text { approach in an organisation does not depend on } \\
\text { the execution of work position analysis. }\end{array}$ & 0.000 & Yes & 0.444 & Substantial \\
\hline 7 & $\begin{array}{l}\text { The utilisation of the competency-based } \\
\text { approach in an organisation does not depend on } \\
\text { the position of the person responsible for human } \\
\text { resource management in top management. }\end{array}$ & 0.036 & Yes & 0.201 & Low \\
\hline
\end{tabular}

Source: own

\subsection{Use of the Competency-Based Approach in Knowledge-Based Organisations}

Knowledge-based organisations are organisations applying a knowledge-based approach to the organisation. This approach perceives organisations as a means for the development, integration, preservation, sharing and application of knowledge. According to Calabrese [5], the twenty-first century has surfaced the need for more flexible and responsive knowledge-based organisations capable of rapidly adjusting to the increasing rate of change and demands in both products and services. Wu, Ong and Hsu [31] state that knowledge-based organisations allocate resources to intangible assets in the rapidly changing and highly competitive business environment in order to gain competitive advantages. Given the presence and complexities of internal and external influences, the manager is often faced with the prospect of reacting to constant changes in the internal and external environment. In order to be effective in that regard the manager must possess these personal characteristics necessary to improve management performance [10].

The survey conducted has revealed that $92.3 \%$ of organisations applying the competency-based approach record knowledge of their employees. Despite the fact that $82.1 \%$ 
of organisations use knowledge bases (created within the organisation); only $20.5 \%$ of them motivate their employees to share, transfer and preserve knowledge in the organisation. Based on the above-stated results, two last hypotheses were tested; see Table 3. Both these hypotheses have been rejected and alternative hypotheses have been accepted. Based on the $\mathrm{X}^{2}$ test, the null hypothesis $\left(\mathrm{H}_{0}\right.$ no. 8) has been rejected at the $5 \%$ level of significance ( $p$-value $=0.015$ ). The strength of the relationship between the variables is, according to the value of $\mathrm{Phi}$ coefficient (0.278), Cramer's coefficient (0.278) and Contingency coefficient (0.268), direct and moderate. Based on the $\mathrm{X}^{2}$ test, the null hypothesis $\left(\mathrm{H}_{0}\right.$ no. 9) has been rejected at the $5 \%$ level of significance ( $p$-value $=0.000$ ). The strength of the relationship between the variables is, according to the value of Phi coefficient (0.415), Cramer's coefficient (0.415) and Contingency coefficient (0.383), direct and substantial. It is possible to say that organisations that utilise the knowledge of their employees realise the importance of knowledge management and perceive their employees as an important asset for achieving a competitive advantage. With respect to the fact that knowledge forms part of competencies, this subsequently facilitates the implementation of the competency-based approach by organisations.

\section{Tab. 3: The results of the qualitative characteristics test for hypotheses no. 8 and 9}

\begin{tabular}{c|l|c|c|c|c}
$\begin{array}{c}\text { Number of } \\
\text { hypothesis }\end{array}$ & \multicolumn{1}{|c|}{ Null hypothesis $\left.\mathbf{H}_{0}\right)$} & P-value & $\begin{array}{c}\text { Rejection } \\
\text { of } \mathbf{H}_{0}\end{array}$ & $\begin{array}{c}\text { Value of Phi } \\
\text { coefficient }\end{array}$ & $\begin{array}{c}\text { Strength of the } \\
\text { relationship }\end{array}$ \\
\hline 8 & $\begin{array}{l}\text { The utilisation of the competency-based } \\
\text { approach in an organisation does not depend on } \\
\text { the application of knowledge management. }\end{array}$ & 0.015 & Yes & 0.278 & Moderate \\
\hline 9 & $\begin{array}{l}\text { The utilisation of the competency-based } \\
\text { approach in an organisation does not depend on } \\
\text { the utilisation of knowledge bases. }\end{array}$ & 0.000 & Yes & 0.415 & Substantial \\
\hline
\end{tabular}

Source: own

\section{Discussion}

The survey has found that organisations in the Czech Republic concentrate on the application of the competency-based approach in areas and activities targeted primarily at managers and specialists, rather than on the application of a competency-based model as a whole. The outcomes provided above also confirm that the application of the competency-based approach in organisations in the Czech Republic depends on the following:

1. the fact whether an organisation is part of a larger group of organisations;

2. personnel management arrangements in an organisation (the existence of a personnel department, the personnel strategy processed in written form, work position analysis execution, the position of the person responsible for human resource management in top management);

3. the application of knowledge management. According to the strength of the relationship between the variables, the most important group of factors is that relating to personnel management organisation. No dependency on the size of organisations and sector in which organisations operate has been proven.

The above-said means that if organisations employ the competency-based approach, they do not use individual activities (competency identification, competency-based model development, competency level measuring, competency development) within their frame on an equal basis. This is also valid for individual categories of employees (organisations concentrate in particular on managers and specialists). The majority of surveyed organisations using the competency-based approach place major focus on competency identification; other related activities lag behind. This means there is no synergic effect which would occur in the event of the implementation of the competency-based approach as a whole. According to Abraham et al. [1], organisations that aspire to be high-performance organisations should be encouraged not only to competencies identification. These results are 
confirmed also by Martin and Pope [16], who also point out that studies revealed that in most organisations inflexible competency models are utilized and many of them are not sufficiently transparent and dynamic to be used effectively in today's varying organisations.

In compliance with the resourcebased approach to competitive advantage development, it is the employees who become, due to their competencies, an important source for achieving a competitive advantage. The importance of competencies to organisations cannot be overstated; in fact, they can be the key to competitive advantage [6]. Competency management plays an important role in individual and organisational levels in the following areas: (1) strategic workforce planning, (2) recruitment, (3) selection, (4) performance appraisal, (5) training, (6) education and development, (7) talent management, (8) career management, (9) performance management, (10) succession planning, and (11) rewarding and recognition [25], [13], [1], [15], [9], [24], [19], [27], [22]. Vazirani [27] adds that competencies and competency models are a viable tool that can be utilized to prepare the current and future workforce and retain skilled incumbent employees. Furthermore, competencies and competency models are an assistive device for individuals to focus on their current competencies and refocus or enhance their competencies as necessary. With the knowledge and use of the information contained within a competency model and awareness of their individual competency strengths and weaknesses, individuals may manage their future job or career success, navigate their current chosen career pathway, or apply the information to examine new career opportunities [27].

\section{Conclusion}

Based on the evaluation of the survey targeted at the use of the competency-based approach in organisations in the Czech Republic, it is possible to state that despite the fact that the application of the competency-based approach has a demonstrable impact on the fulfilment of organisations' strategic goals; it is applied by only $35.8 \%$ of responding organisations. They include in particular small and large organisations. Important factors that determine the use of the competency-based approach in these organisations include: the affiliation with a larger group of organisations, the high level of personnel management organisation and the application of knowledge management which facilitates the application of the competencybased approach by organisations. With respect to the above said organisations are recommended to focus on the application of the competency-based approach as a whole, which will trigger the required synergic effect and contribute to the efficient utilisation of competencies in management. In the fully integrated human resource management system employing the competency-based approach, competencies represent a key prerequisite for efficient performance. This will subsequently bring benefits at both the organisational and individual levels.

The article has been prepared with the support of the Czech Science Foundation GP 402/09/P616 "Use of Competencies in Knowledge-Based Organisation".

\section{References}

[1] ABRAHAM, S. E., KARNS, L. A., SHAW, K. and MENA, M. A. Managerial competencies and the managerial performance appraisal process. The Journal of Management Development. 2001, Vol. 20, No. 9/10, pp. 842-852. ISSN 0262-1711. doi:http://dx.doi. org/10.1108/02621710110410842.

[2] BIRDIR, K., PEARSON, T. Research Chefs' Competencies: A Delphi Approach. International Journal of Contemporary Hospitality Management. 2000, Vol. 12, No. 3, pp. 205-209. ISSN 0959-6119. doi:http://dx.doi. org/10.1108/09596110010309989.

[3] BOYATZIS, R. E. The Competent Manager: A Model for Effective Performance. New York: John Villey and Sons, 1982. ISBN 0-471-09031-X. [4] BOYLES, T. $21^{\text {st }}$ century knowledge, skills, and abilities and entrepreneurial competencies: A model for undergraduate entrepreneurship education. Journal of Entrepreneurship Education. 2012, Vol. 15, pp. 41-56. ISSN 1098-8394.

[5] CALABRESE, F. A. Knowledge-based Organizations in Context. VINE. The Journal of Information and Knowledge Management Systems. 2006, Vol. 36, No. 1, pp. 12-16. ISSN 0305-5728. doi:http://dx.doi. org/10.1108/03055720610667318.

[6] CARDY, R. L. and SELVARAJAN, T. T. Competencies: Alternative frameworks for competitive advantage. Business Horizons. 2006, Vol. 49, No. 3, pp. 235-245. ISSN 00076813. doi:10.1016/j.bushor.2005.09.004. 
[7] CHONG, E. Managerial competencies and career advancement: A comparative study of managers in two countries. Journal of Business Research. 2013, Vol. 66, No. 3, pp. 345-353. ISSN 0148-2963. doi:10.1016/j. jbusres.2011.08.015.

[8] DE VAUS, D. Surveys in Social Research. London: Routledge/Taylor and Francis, 2002. ISBN 978-0415268585.

[9] GRIGORYEV, P. Hiring by Competency Models. The Journal for Quality and Participation. 2006, Vol. 29, No. 4, pp. 16-18. ISSN 1040-9602.

[10] HESS, J. D. and BACIGALUPO, A. C. The Emotionally Intelligent Leader, the Dynamics of Knowledge-Based Organizations and the Role of Emotional Intelligence in Organizational Development. On the Horizon. 2010, Vol. 18, Iss. 3, pp. 222-229. ISSN 1074-8121. doi:http:// dx.doi.org/10.1108/10748121011072672.

[11] HITT, M. A., IRELAND, R. D. and HOSKISSON, R. E. Strategic management: Concepts and Cases: Competitiveness and globalization. Versailles, KY: South-Western, 2012. ISBN 978-1111825874.

[12] HORNG, J. S., HSU, H., LIU, CH. H., LIN, L. and TSAI, CH. Y. Competency Analysis of Top Managers in the Taiwanese Hotel Industry. International Journal of Hospitality Management. 2011, Vol. 30, Iss. 4, pp. 1044-1054. ISSN 0278-4319. doi:10.1016/j. ijhm.2011.03.012.

[13] LUCIA, A. D. and LEPSINGER, R. The Art and Science of Competency Models: Pinpointing Critical Success Factors in Organizations. San Francisco: Jossey-Bass/ Pfieffer, 1999. ISBN 0-7879-4602-8.

[14] MANSFIELD, R. S. Practical Questions in Building Competency Models. Fort Lauderdale, Florida: Workitect, 2005. 18 p. Available also from: https://www.lexonis.com/resources/ practical $\% 20$ questions $\% 20$ building $\% 20$ models.pdf.

[15] MARRELLI, A. F., TONDORA, J. and HOGE, M. A. Strategies for developing competency models. Administration and Policy in Mental Health. 2005, Vol. 32, Iss. 5-6, pp. 533-561. ISSN 0894-587X. doi:10.1007/ s10488-005-3264-0.

[16] MARTIN, P. D. and POPE, J. Competencybased interviewing - has it gone too far? Industrial and Commercial Training. 2008, Vol. 40, No. 2, pp. 81-86. ISSN 0019-7858. doi:http:// dx.doi.org/10.1108/00197850810858910.
[17] MCCLELLAND, D. C. Testing for Competence Rather Than for Intelligence. American Psychologist. 1973, Vol. 28, Iss. 1, pp. 1-14. ISSN 0003-066X. doi: http://dx.doi. org/10.1037/h0034092.

[18] MITCHELMORE, S. and ROWLEY, J. Entrepreneurial competencies: a literature review and development agenda. International Journal of Entrepreneurial Behaviour \& Research. 2010, Vol. 16, No. 2, pp. 92-11. ISSN 1355-2554. doi:10.1108/13552551011026995.

[19] NOE, R. A. Employee Training and Development. New York: McGraw-Hill, 2008. ISBN 978-0390147530.

[20] PABLOS, P. O. and LYTRAS, M. D. Competencies and human resource management: implications for organizational competitive advantage. Journal of Knowledge Management. 2008, Vol. 12, No. 6, pp. 48-55. ISSN 1367-3270. doi:http://dx.doi.org/10.1108/13673270810913612. [21] PANDIAN, J. P. and MCKIERNAN, P. Competence-based management and strategic alliances. In: SANCHEZ, R. and HEENE, A. (Eds.). Competence Perspectives on Managing Interfirm Interactions. Advances in Applied Business Strategy. Vol. 8. Burlington: Emerald Group Publishing Limited, 2005. ISBN 978-1-84950-321-1.

[22] POORKIANI, M., BEHESHTIFAR, M. and MOGHADAM, M. N. Studying the CompetencyRelated Models in Succession Planning. The Social Sciences. 2010, Vol. 5, No. 6, pp. 507-513. ISSN 1993-6125. doi:10.3923/ sscience.2010.507.513.

[23] SANCHEZA, J. I. and LEVINE, E. L. What is (or should be) the difference between competency modelling and traditional job analysis? Human Resource Management Review. 2009, Vol. 19, Iss. 2, pp. 53-63. ISSN 1053-4822. doi:10.1016/j.hrmr.2008.10.002.

[24] SANGHI, S. The Handbook of Competency Mapping. New Delhi: Sage Publications India, 2007. ISBN 9780761935988.

[25] SPENCER, L. M. and SPENCER, S. M. Competence at Work. New York: John Wiley and Sons, 1993. ISBN 0-471-54809-X.

[26] TATE, W. Developing Managerial Competence. Hampshire: Gower Publishing Limited, 1995. ISBN 0-566-07475-3.

[27] VAZIRANI, N. Competencies and Competency Model-A Brief overview of its Development and Application. SIES Journal of Management. 2010, Vol. 7, No. 1, pp. 121-131. ISSN 0974-2956. 
[28] WHITE, R. Motivation Reconsidered: the Concept of Competence. Psychological Review. 1959, Vol. 66, No. 5, pp. 279-333. ISSN 0033295X. doi:http://dx.doi.org/10.1037/h0040934. [29] WINTERTON, J. and WINTERTON, R. Developing Managerial Competence. London: Routledge, 1999. ISBN 0-415-18345-6.

[30] WOODALL, J. and WINSTANLEY, D. Management Development: Strategy and Practice. Oxford: Blackwell, 1998. ISBN 9780631198666.

[31] WU, L. C., ONG, CH. S. and HSU, Y. W. Knowledge-Based Organizations Evaluation. Decision Support Systems. 2008, Vol. 45, Iss.
3, pp. 541-549. ISSN 0167-9236. doi:10.1016/j. dss.2007.06.013.

Ing. Martina Fejfarová, Ph.D. Czech University of Life Sciences Prague Faculty of Economics and Management

Department of Management fejfarovam@pef.czu.cz

Ing. Hana Urbancová, Ph.D. Czech University of Life Sciences Prague Faculty of Economics and Management Department of Management urbancova@pef.czu.cz 


\section{Abstract}

\section{APPLICATION OF THE COMPETENCY-BASED APPROACH IN ORGANISATIONS IN THE CZECH REPUBLIC}

\section{Martina Fejfarová, Hana Urbancová}

A competency-based approach is one of the important tools of human resource management aimed at achieving strategic organisational goals and a competitive advantage. The article focuses on application of the competency-based approach in organisation in the Czech Republic. The first part of the article concentrates on the theoretical background. The second part evaluates the results of the quantitative survey. The aim of the article is to evaluate the competency-based approach in organisations in the Czech Republic and also to identify areas and activities in which the competencybased approach is applied and test dependencies between selected qualitative characteristics that relate to the issues examined. The results of the survey show that if organisations employ the competency-based approach (35.8\%), they do not use individual activities within their frame on an equal basis. This is also valid for individual categories of employees (organisations concentrate in particular on managers and specialists). The results further confirm that the application of the competency-based approach in organisations in the Czech Republic depends on the fact whether an organisation is part of a larger group of organisations ( $p$-value $=0.003$, Phi coefficient $=0.238$ ); personnel management arrangements in an organisation (the existence of a personnel department $(p$-value $=0.001$, Phi coefficient $=0.316)$, processed personnel strategy $(p$-value $=0.006$, Phi coefficient $=0.310)$, work position analysis execution ( $p$-value $=0.000$, Phi coefficient $=0.444)$, the position of the person responsible for human resource management in top management ( $p$-value $=$ 0.036 , Phi coefficient $=0.201)$ ) and the application of knowledge management ( $p$-value $=0.015$, Phi coefficient $=0.278$ ). According to the strength of the relationship between the variables, the most important group of factors is that relating to personnel management organisation. No dependency on the size of organisations and sector in which organisations operate has been proven.

Key Words: Competency-based approach, competencies, competency models, human resource management, competitive advantage, survey.

JEL Classification: M12.

DOI: 10.15240/tul/001/2015-1-009 